\title{
Carbonyl compounds in wine: factors related to presence and toxic effects
}

\section{Laura Oliveira Lago ${ }^{1}$ Juliane Elisa Welke $^{{ }^{*}}$}

${ }^{1}$ Instituto de Ciência e Tecnologia de Alimentos (ICTA), Universidade Federal do Rio Grande do Sul (UFRGS), 91501-970, Porto Alegre, RS, Brasil. E-mail: juliane.welke@ufrgs.br. "Corresponding author.

ABSTRACT: The objective of this study was to review technological and toxicological factors related to presence of carbonyl compounds found in wines, including acetaldehyde, formaldehyde, acrolein, ethyl carbamate (EC) and furfural. Acetaldehyde and formaldehyde may be formed through the ethanol and methanol oxidation, respectively. Acrolein may arise as a thermal degradation product of glycerol, amino acids, carbohydrates and triglycerides or by metabolic activity of microorganisms. In addition, acrolein and furfural are formed during wood combustion; therefore, these aldehydes may be present in raw materials due to the environmental contamination. Furfural is also a product of the Maillard reaction formed from sugars and amino acids, while ethyl carbamate occurs through the reaction between urea and ethanol. These compounds may react with $\mathrm{SO}$, and phenolic compounds to form non-volatile adducts, which positively modulates color stability, astringency and aroma in wine. However, when ingested through wine, electrophilic carbonyl compounds may form adducts with nucleophilic targets, such as DNA, resulting in genotoxicity along the gastrointestinal tract. Furthermore, carbonyl compounds induce the increase of reactive oxygen species and can trigger apoptosis, in addition to hepatocellular adenoma and carcinoma as a consequence of chronic hepatotoxicity. Neurodegenerative diseases may be related to the exposure to carbonyl compounds. Therefore, strategies to reduce the levels of these compounds should be studied in order to get the most out of the beneficial functional properties of wine consumption. Key words: acetaldehyde, formaldehyde, ethyl carbamate, furfural, acrolein.

Compostos carbonílicos em vinho: fatores relacionados a presença e efeitos tóxicos

RESUMO: O objetivo deste estudo foi revisar os fatores tecnológicos e toxicológicos relacionados à presença de compostos carbonílicos encontrados em vinhos, incluindo acetaldeído, formaldeído, acroleina, carbamato de etila (CE) e furfural. $O$ acetaldeído e o formaldeído podem ser formados através da oxidação do etanol e do metanol, respectivamente. A acroleína pode surgir como um produto de degradação térmica de glicerol, aminoácidos, carboidratos e triglicerídeos ou pela atividade metabólica de microorganismos. Além disso, a acroleína e o furfural são formados durante a combustão da madeira. Portanto, esses aldeídos podem estar presentes nas matérias-primas devido à contaminação ambiental. O furfural é também um produto da reação de Maillard formado a partir de açúcares e aminoácidos, enquanto o carbamato de etila ocorre através da reação entre uréia e etanol. Estes compostos podem reagir com $\mathrm{SO}_{2}$ e compostos fenólicos para formar adutos não voláteis, que modulam positivamente a estabilidade da cor, adstringência e aroma no vinho. No entanto, quando ingeridos através do vinho, os compostos carbonílicos que são eletrofilicos podem formar adutos com alvos nucleofilicos, como o DNA, resultando em genotoxicidade ao longo do trato gastrintestinal. Além disso, os compostos carbonilicos também induzem o aumento de espécies reativas de oxigênio e podem desencadear a apoptose, além de adenoma e carcinoma hepatocelular como consequência da hepatotoxicidade crônica. Doenças neurodegenerativas podem estar relacionadas à exposição aos compostos carbonílicos. Com isso, estratégias para reduzir os niveis desses compostos devem ser estudadas para obter o máximo das propriedades funcionais benéficas do consumo de vinho.

Palavras-chave: acetaldeído, formaldeído, carbamato de etila, furfural, acroleina.

\section{INTRODUCTION}

Wine has been associated to beneficial properties derived from its moderate consumption. These effects are mainly observed due to the presence of phenolic compounds that reduce the risk of cardiovascular diseases and have antioxidant and anti-inflammatory properties (HASEEB et al., 2017). However, among compounds present in wines, there are carbonyl compounds, including acetaldehyde, acrolein, formaldehyde, ethyl carbamate (EC) and furfural (FERREIRA et al., 2019). Figure 1A shows the chemical structure highlighting the presence of the carbonyl group of these compounds.

The carbonyl group gives electrophilicity to these compounds and therefore high reactivity with the nucleophiles cellular constituents (SEMCHYSHYN, 2014). According to the electrophilic theory applied 
to toxicology, most of chemical carcinogens and/or their active metabolites are electrophiles that form covalent bonds with DNA (ZHANG et al., 2016). Figure $1 \mathrm{~B}$ shows the adduct formation resulted from the reaction between the carbonyl group $(-\mathrm{C}=\mathrm{O}$, electrophile group) of acetaldehyde and the amine group (- $\mathrm{NH}_{2}$, nucleophilic group) of deoxyguanosine of DNA. Furthermore, an increase of the exposure to reactive carbonyls is the key cause of the phenomenon named carbonyl stress, a contributing factor to aging, hepatic injury, neurodegenerative diseases and other disorders, such as diabetes and renal failure (SEMCHYSHYN, 2014).

The International Agency for Research on Cancer (IARC) classifies the acetaldehyde ingested specifically through alcoholic beverages as carcinogenic to humans (group 1). Formaldehyde is also in group 1 and $\mathrm{EC}$ is defined as probable carcinogenic to humans (group 2A). Acrolein and furfural are in group 3, in which the IARC needs further study to classify this compound regarding carcinogenic effects (IARC, 2019). The Joint FAO/WHO Experts Committee on Food Additives (JECFA) has not established safe intake parameters for formaldehyde, acetaldehyde, acrolein and EC. However, furfural is considered food flavouring; therefore there is an acceptable daily intake of $0.5 \mathrm{mg}$ per $\mathrm{kg}$ of body weight setted by JECFA for the sum of exposure to furan-containing compounds, which includes the furfural furfuryl (alcohol, acetate, propionate, pentanoate, octanoate, 3-methylbutanoate), and 2-furoate compounds (methyl, propyl, amyl, hexyl, and octyl) (JECFA, 2018).

The occurrence of these compounds was reported in grape wines from Brazil, Germany, Hungary, Portugal and Australia as shown in table 1. It is important to mention that these compounds have also been evaluated in rice wine traditionally consumed in Asian countries (Table 1).

Several factors may contribute to the presence of carbonyl compounds in wines, including the advancement of the ripeness degree and increasing the maceration time, which resulted in higher levels of carbonyl compounds in Syrah wines from Vale do São Francisco region (Brazil), probably due to

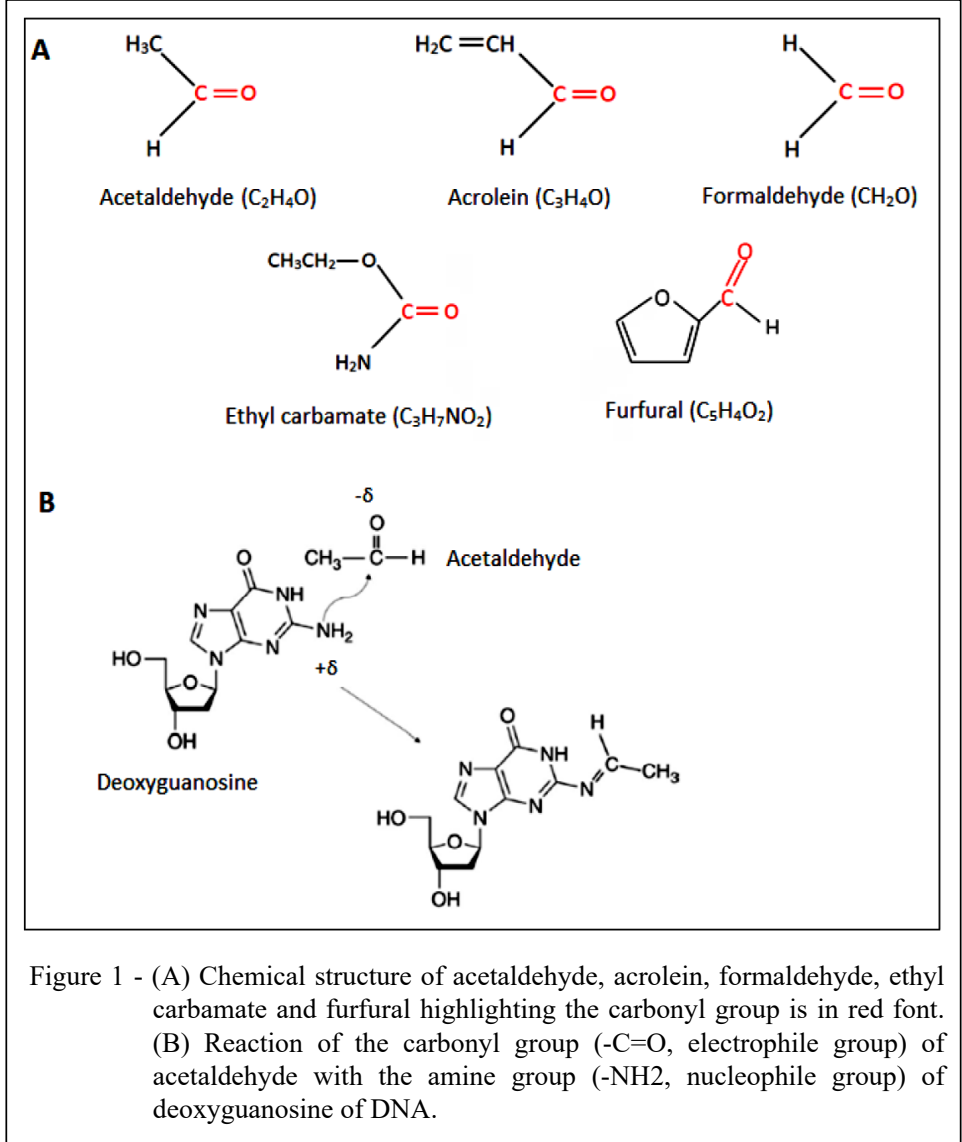

Ciência Rural, v.49, n.8, 2019. 
increased concentration of the precursors (amino acids, glucose, among others) in the must (LAGO et al., 2017). FERREIRA et al. (2019) found acrolein and furfural in Merlot musts and in the respective wines elaborated in Campanha Gaúcha region (Brazil); although, levels declined throughout the winemaking process. Similar results regarding acrolein and furfural were reported by FERREIRA et al. (2018) in the evaluation of grape, must and fermentation (alcoholic and malolactic) of Merlot vinification of the same region. In addition, formaldehyde was found in all these stages of wine production; however, at levels lower than the limit of quantification of the method $\left(1.0 \mu \mathrm{g} \mathrm{L}^{-1}\right)$ and ethyl carbamate was not present in samples (FERREIRA et al., 2018). Therefore, the potential environmental contamination of grapes with acrolein and furfural are critical points related to the presence of toxic carbonyl compounds in the wine (FERREIRA et al., 2018; 2019). This aldehyde seems to be a precursor of acetoin and 2,3-butanediol, since the levels of acrolein decreased along winemaking of Merlot grapes, while the formation of the respective ketone and alcohol was verified. Furfural levels diminished, whereas the occurrence of other furancontaining compounds increased during winemaking (FERREIRA et al., 2018).

There are no restrictions established by legislation for these compounds in wines, with the exception of Canada (30 $\left.\mu \mathrm{g} \mathrm{L}^{-1}\right)$, Czech Republic (30 $\left.\mu \mathrm{g} \mathrm{L}^{-1}\right)$ and United States of America $\left(15 \mu \mathrm{gL}^{-1}\right)$ where maximum limits have been defined for $\mathrm{EC}$ in wine. Regarding the exposure to formaldehyde and acrolein, the International Program on Chemical Safety (IPCS) of the World Health Organization (WHO) recommended maximum tolerable concentrations of 2600 and $1500 \mu \mathrm{g} \mathrm{L}^{-1}$, respectively (IPCS, 2002).

The objective of this study was for the first time to review the technological e toxicological factors related to presence of the carbonyl compounds found in wine, with focus on those compounds that have classification according carcinogenicity by the IARC. To our knowledge there is no review covering these aspects of the target compounds of this study published in the literature. The databases used in this approach were PubMed, Google Scholar and Scopus. Searches of the published literature were performed

Table 1 - Carbonyl compounds (acetaldehyde, formaldehyde, ethyl carbamate, acrolein and furfural) evaluated in wines.

\begin{tabular}{|c|c|c|c|c|}
\hline Carbonyl compound & Wine type & Place of production & Concentration range [mean] $\left(\mu \mathrm{g} \mathrm{L}^{-1}\right)$ & Reference \\
\hline \multirow{3}{*}{ Acetaldehyde } & Rice & South Korea & $4990-11570[8280]$ & CHUNG et al., 2015 \\
\hline & Syrah & Brazil & $51-635[213]$ & LAGO et al., 2017 \\
\hline & Merlot & Brazil & $1.6-113.5[26.2]$ & FERREIRA et al., 2018 \\
\hline \multirow{3}{*}{ Acrolein } & $\mathrm{NI}^{\mathrm{a}}$ & Germany & $\mathrm{ND}^{\mathrm{b}}-8.8[0.7]$ & KÄCHELE et al., 2014 \\
\hline & Syrah & Brazil & $8.4-410[72]$ & LAGO et al., 2017 \\
\hline & Merlot & Brazil & $0.8-29.8[15.9]$ & FERREIRA et al., 2018 \\
\hline \multirow{6}{*}{ Ethyl carbamate } & NI & Hungary & $4.9-39.9[17.7]$ & AJTONY et al. , 2013 \\
\hline & Rice & China & ND-225 [76.3] & ZHANG et al. , 2014 \\
\hline & Syrah & Brazil & $14.1-30.8[21.8]$ & NÓBREGA et al., 2015 \\
\hline & Syrah & Brazil & $17-242[100]$ & LAGO et al., 2017 \\
\hline & Merlot & Brazil & $\mathrm{ND}^{\mathrm{b}}$ & FERREIRA et al., 2018 \\
\hline & Fortified & Portugal & $23-194[71.9]$ & LEÇA et al., 2018 \\
\hline \multirow{4}{*}{ Formaldehyde } & Rice & China & {$[0.2]^{\mathrm{c}}$} & LACHENMEIER et al., 2013 \\
\hline & Red & South Korea & {$[40.9]^{\mathrm{c}}$} & JEONG et al., 2015 \\
\hline & Syrah & Brazil & $23-206[64]$ & LAGO et al., 2017 \\
\hline & Merlot & Brazil & $<0.6^{\mathrm{d}}$ & FERREIRA et al., 2018 \\
\hline \multirow{5}{*}{ Furfural } & Rosé & Australia & ND-961 [192] & WANG et al., 2016a \\
\hline & Rosé & Australia & ND-1414 [149] & WANG et al., 2016b \\
\hline & Madeira & Portugal & $\begin{array}{l}\text { Sweet: }[2540]^{\mathrm{c}} \\
\text { Dry: }[3010]^{\mathrm{c}}\end{array}$ & PERESTRELO et al., 2017 \\
\hline & Syrah & Brazil & $84-1715$ [184] & LAGO et al., 2017 \\
\hline & Merlot & Brazil & $1.6-227.9[58.2]$ & FERREIRA et al., 2018 \\
\hline
\end{tabular}

${ }^{a}$ Not informed; ${ }^{b}$ Not detected; values lower than the limit of detection of the method, $<1 \mu \mathrm{g} \mathrm{L}^{-1}$; ${ }^{\mathrm{c}}$ concentration range has not been reported; ${ }^{d}$ levels were below the limit of quantification of the method $\left(0.6 \mu \mathrm{g} \mathrm{L}^{-1}\right)$. 
using the following key words: "formaldehyde", "'ethyl carbamate", ' acetaldehyde", "furfural" and "acrolein" in addition to: wine, oxidation, toxicity, cytotoxicity, genotoxicity, carcinogenicity, oxidative stress, DNA-protein crosslinks, DNAadducts and apoptosis. Articles from 2001 to 2019 were included in this review.

\section{Acetaldehyde}

Acetaldehyde occurs during fermentation from sugars (mainly glucose and fructose), which are metabolized by yeast via pyruvate decarboxylase and alcohol dehydrogenase (JACKOWETZ et al., 2011). Acetic acid bacteria originating from grapes and winery equipment can also produce this aldehyde through the oxidation of ethanol via alcohol dehydrogenase. Moreover, acetaldehyde can be formed by non-enzymatic oxidation throughout storage and aging of wine (SHERIDAN, ELIAS, 2015). During wine oxidation, iron (II) reduces oxygen to the hydroperoxyl radical, which converts wine hydroquinones into quinones and hydrogen peroxide $\left(\mathrm{H}_{2} \mathrm{O}_{2}\right)$. Ferrous ion associated to $\mathrm{H}_{2} \mathrm{O}_{2}$ generates hydroxyl radical that can react with ethanol to yield acetaldehyde (PICARIELLO et al., 2017).

Sulfur dioxide $\left(\mathrm{SO}_{2}\right)$, added to wine to prevent both oxidation reactions and contaminating microorganisms, reacts with $\mathrm{H}_{2} \mathrm{O}_{2}$, and therefore, inhibits acetaldehyde production (OLIVEIRA et al., 2011). Furthermore, $\mathrm{SO}_{2}$ may be spontaneously transformed into bisulfite ion $\left(\mathrm{HSO}_{3}^{-}\right)$due to the wine $\mathrm{pH}$ (from 3 to 4 ). This ion reacts with acetaldehyde to form a non-volatile adduct named $\alpha$-hydroxyethanesulfonic acid, which formation prevents the perception of the unpleasant flavor of this aldehyde (AZEVEDO et al., 2007).

It is important to note that the acetaldehyde modulates wine color, astringency and aroma (SHERIDAN, ELIAS, 2015). Red wines may be produced using micro-oxygenation to improve color stability and flavor. During this process, ethanol oxidation results in acetaldehyde, which reacts with anthocyanins, flavan-3-ols and glycerol, originating stable pigments, lower astringency and cyclic acetals characterized by sweet odor (OLIVEIRA et al., 2011; PICARIELLO et al., 2017).

Despite beneficial effects of the bound form of acetaldehyde for wine quality, the exposure to this aldehyde showed mutagenicity by inducing DNA damage through sister chromatid exchanges and chromosomal aberrations in mammalian cells, as well as by elevating micronuclei formation (tumor biomarker) in human lymphocytes (ERIKSSON,
2015). Acetaldehyde cytotoxicity was verified via induction of apoptosis of human neuroblastoma SH-SY5Y cells by downregulating the expression of antiapoptotic Bcl-2 and Bcl-xL and upregulating the expression of proapoptotic Bax (family of proteins that regulate apoptotic pathway by affecting the permeability of the mitochondrial outer membrane). In addition, the overproduction of reactive oxygen species (ROS) leading to oxidative stress was also reported when this neuroblastoma cells were exposed to acetaldehyde (YAN et al., 2016). In another approach, this aldehyde induced neuroepithelial cell death, which may be correlated to the structural malformations observed in the fetal alcohol syndrome, suggesting that acetaldehyde is a teratogenic compound (MENEGOLA et al., 2001).

In the human body, ethanol is metabolized to acetaldehyde by alcohol dehydrogenase (ADH) enzyme, and in turn, acetaldehyde is converted by aldehyde dehydrogenase (ALDH) enzyme to acetate. These enzymes exhibit distinct tissue distribution, being expressed in upper (mouth, pharynx, esophagus and stomach) and lower digestive tract and liver (FUJIOKA, GORDON, 2018). Moreover, microorganisms present in normal oral or gut microbiota can produce acetaldehyde from ethanol. A mutation in the gene that encodes ALDH, enzyme responsible for the oxidation of acetaldehyde to acetate during alcohol metabolism, increases the risk for cancer, in particular for oesophageal cancer. This situation can occur because carriers of the inactive ALDH enzyme process acetaldehyde at a much slower rate, which leads to accumulation of this aldehyde in saliva, blood and tissues after alcohol consumption (LEWIS, SMITH, 2005).

\section{Acrolein}

Acrolein is spontaneously formed in wines through the dehydration of 3-HPA, which occurs from the enzymatic hydrolysis of glycerol by lactic acid bacteria (LAB, Lactobacillus and Oenococcus genera). Glycerol is the third major product (after ethanol and carbon dioxide) of action of yeasts during alcoholic fermentation (BAUER et al., 2010a).

Acrolein may react with $\mathrm{SO}_{2}$ and polyphenols, and this adduct results in bitterness that impairs the sensory quality of wine (BAUER et al., $2010 b$ ). In addition, concentrations of free $\mathrm{SO}_{2}$ from 20 to $40 \mathrm{mg} \mathrm{L}^{-1}$ inhibit the LAB metabolism by reducing the activity of ATPase enzyme; therefore, preventing the formation of acrolein (CARRETÉ et al., 2002).

Acrolein plays an important role in some cardiovascular, neurodegenerative and hepatic 
diseases via mechanisms involving cytotoxicity (ISMAHIL et al., 2011; HUANG et al., 2013; WANG et al., 2017; CHEN et al., 2016). Oral long-term exposure to acrolein promoted upregulation of a cytokine named tumor necrosis factor alpha (TNF- $\alpha$ ), which prompts myocyte apoptosis and consequently, chronic heart failure in mice (ISMAHIL et al., 2011). In rats, oral intake of this aldehyde induced Alzheimer's disease-like pathologies such as mild cognitive declination and hippocampal atrophy (HUANG et al., 2013). Symptoms of Parkinson's disease were also related to the acrolein exposure in rats due to the aggregation of the neuronal protein alpha-synuclein and the initiation of dopaminergic cell death (WANG et al., 2017). In addition, the accumulation of acrolein-protein adducts triggered endoplasmic reticulum stress in rat hepatocytes along with apoptosis, steatosis and hepatic injury that are recognized etiologic factors in alcoholic liver disease (CHEN et al., 2016).

\section{Ethyl carbamate (EC)}

$\mathrm{EC}$ is formed from the reaction between ethanol and nitrogen-containing compounds, including urea, citrulline and carbamoyl phosphate. Arginine is one of the majority amino acid of wine, which is enzymatically degraded throughout the vinification. During alcoholic fermentation, Saccharomyces cerevisiae hydrolyzes this amino acid resulting in urea, while in the malolactic fermentation (ML), LAB decomposes arginine producing citrulline and carbamyl phosphate (JIAO et al., 2014). The reaction between ethanol and these precursors can be potentiated according to the storage temperature of the wine. Levels of this ester were 7 times higher in rice wine stored at $37{ }^{\circ} \mathrm{C}\left(509 \mu \mathrm{g} \mathrm{L}^{-1}\right)$ compared to wine kept at $4{ }^{\circ} \mathrm{C}$ (84 $\mathrm{g} \mathrm{L} \mathrm{L}^{-1}$ ) for 400 days (WU et al., 2014). Aging is also responsible for the 5-fold increase in EC. In addition, the type of aging may also play a role on this compound since when performed in oak casks resulted in higher EC levels $\left(57.4 \mu \mathrm{g} \mathrm{L}^{-1}\right)$ than wines aged for the same period of time in stainless steel tanks $\left(47.3 \mu \mathrm{g} \mathrm{L}^{-1}\right)$. This difference may be due to microbiological modifications favored under the low aeration that takes place because of the pores of the oak cask, which would increase the precursors of EC for those wines aged in wood (RUIZ-BEJARANO et al., 2015).

EC toxicity is connected to its metabolization into vinyl carbamate epoxide via cytochrome P450 2E1, especially in liver. This electrophilic specie can bind covalently to the DNA forming an adduct; and therefore, has mutagenic and carcinogenic potential (LAJOVIC et al., 2015). The generation of ROS has also been related to exposure to EC, triggering oxidative stress and cell death via energy depletion and disruption of cells membrane integrity (LIU et al., 2017). Overproduction of ROS may result in genomic alterations such as mutations and deletions, which further facilitates progression of pre-neoplastic cells to the malignant form, increasing the risk of cancer. In rodents, the oral exposure to EC has shown to contribute for triggering tumors in liver, mammary gland and ovarian (CUI et al., 2016).

\section{Formaldehyde}

Formaldehyde is formed during alcoholic fermentation through the oxidation of methanol, which occurs in the hydrolysis of pectin present in grape (DOROKHOV et al., 2015). Moreover, the presence of formaldehyde in wine may be derived from the use of disinfectants containing this aldehyde for the hygiene of the winery equipment (LACHENMEIER et al., 2013).

Similarly to the above-mentioned about acetaldehyde and acrolein, formaldehyde also binds to phenolic compounds and/or $\mathrm{SO}_{2}$, which occurs from maceration to aging and decreases the levels of these free aldehydes in wine (PISSARRA et al., 2003; AZEVEDO et al., 2007). PISSARRA et al. (2003) showed that aldehydes as formaldehyde could mediate condensation between an anthocyanin (malvidin 3-glucoside) and a flavanol [(+)-catechin] resulting in the formation of red polymeric pigments with increase in wine color stability. AZEVEDO et al. (2007) reported that approximately $90 \%$ of the formaldehyde is present in the bound form to $\mathrm{HSO}_{3}{ }^{-}$ named hydroxymethanesulfonic acid.

The oxidation of formaldehyde into formate is catalyzed by $S$. cerevisiae enzymes specifically dehydrogenases (aldehyde and alcohol) and S-formylglutathione hydrolase. Therefore, the use of yeast strains with genetic modifications in these enzymes can increase the conversion of formaldehyde to formate, reducing the concentration of this compound in the wine (JAYAKODY et al., 2016).

Administration of formaldehyde through drinking water caused necrosis and hydropic degeneration (edema) in the gastric mucosa cells of rats. On account of the high reactivity of formaldehyde, its effects in the tissue at first contact following ingestion may be pronounced and the extent of the histopathological changes is proportional to the formaldehyde concentration (DAVID, ARKEMAN, 
2008). Furthermore, this aldehyde has been shown to lead death of SK-N-SH neuroblastoma cells due to oxidative stress, which decline the mitochondria potential and consequently, the cellular ATP level, inducing apoptosis (ZERIN et al., 2015).

\section{Furfural}

Furfural may arise in wines due to exposure of grapes to smoke emissions from wildfire events and atmospheric pollution related to industrial/domestic activities and/or burning garbage. Pyrolysis of wood constituents (cellulose, hemicellulose and lignin) resulted in a complex mix of volatile organic compounds, including furan derivatives (KRSTIC et al., 2015). Among these furan-containing compounds, furfural is the only carbonyl compound that has classification according to IARC (group 3) (IARC 2019).

Some steps of winemaking such as maceration and aging can occur in contact with toasted wood through barrels or chips. In heat treatment of wood, some components like hemicelluloses are degraded to pentoses (xylose), which undergo dehydration resulting in furfural (PERESTRELO et al., 2017). The wood type and heating conditions used in toasting influence the furfural levels (GONZÁLEZCENTENO et al., 2019; PERESTRELO et al., 2017; MARTÍNEZ-GIL et al., 2018).

Maceration of Carménère wines in Romanian oak chips (Quercus petraea) resulted in higher furfural content $\left(2192.31 \mu \mathrm{g} \mathrm{L}^{-1}\right)$ than wines treated with French (Quercus petraea; $1484.77 \mu \mathrm{g}$ $\mathrm{L}^{-1}$ ), American (Quercus alba; $1421.67 \mu \mathrm{g} \mathrm{L}^{-1}$ ) or Colombian oak (Quercus humboldtii; $511.08 \mu \mathrm{g} \mathrm{L}^{-1}$ ), showing that concentration of furanic compounds can be influenced by the specie/origin of oak due to differences in the levels of furfural precursors such as hemicelluloses (MARTÍNEZ-GIL et al., 2018). The influence of the wood was also confirmed in the aging of rosé wine in contact with four types of wood chips (Robinia pseudoacacia, Prunus avium, Quercus alba, Quercus petraea), being the lowest and highest furfural levels found in wines aged with wood chips of $R$. pseudoacacia $\left(1350 \mu \mathrm{g} \mathrm{L}^{-1}\right)$ and Q. petraea (2403 $\left.\mu \mathrm{g} \mathrm{L}^{-1}\right)$, respectively (SANTOS et al., 2019). Role of wood heating was verified in the greater furfural concentration $\left(2800 \mu \mathrm{g} \mathrm{L}^{-1}\right)$ in Chardonnay wines aged in French oak barrels (95\% Quercus petraea and $5 \%$ Quercus robur) toasted at $55^{\circ} \mathrm{C}$ for $36 \mathrm{~min}$ than those reported in wines aged in barrels heated at $52{ }^{\circ} \mathrm{C}$ for $36 \mathrm{~min}\left(2000 \mu \mathrm{g} \mathrm{L}^{-1}\right)$ or $60{ }^{\circ} \mathrm{C}$ for $10 \mathrm{~min}\left(2200 \mu \mathrm{g} \mathrm{L}^{-1}\right)$ (GONZÁLEZ-CENTENO et al., 2019). The presence of this aldehyde in the wine may be also attributed to the cork stoppers as result of the thermal degradation of xylose and arabinose found in raw material (oak) (ROCHA et al., 2004).

Furfural is formed in Madeira wines during baking process (named "estufagem"), in which wine remain at $45-50{ }^{\circ} \mathrm{C}$ for 3 months. In this type of wine, this compound is generated during non-enzymatic browning reactions, such as Maillard reactions, involving acid-catalyzed sugar degradation, followed by enolization and $\beta$-elimination of three water molecules (PERESTRELO et al., 2017).

As above mentioned for other aldehydes such as acetaldehyde, acrolein and formaldehyde, furfural has also shown to react directly with phenolic compounds like $(+)$-catechin. This reaction results in compounds that contribute to decrease astringency, which may be desirable for wine quality (ES-SAFI et al., 2002).

Among the target carbonyl compounds described in this review, furfural is the least studied in relation to toxicity. This aldehyde proved to be genotoxic in studies (in vitro) using hamster ovary cells and human lymphocytes by inducing sister chromatid exchange during DNA replication (EFSA, 2004). However, in a study (in vivo) the formation of liver tumors in rodents occurred due to non-genotoxic mechanisms associated with cytotoxicity, affecting both hepatic cytosolic and mitochondrial enzyme activities (LAKE et al., 2001).

\section{CONCLUSION}

Carbonyl compounds occur as free forms or bound to wine constituents. These compounds may react with $\mathrm{SO}_{2}$ and phenolic compounds to form nonvolatile adducts, which positively modulates color stability, astringency, and aroma in wine. However, in the toxicological perspective, when these electrophilic compounds are in the free form, they are readily available to form adducts with biological nucleophilic targets such as proteins, RNA and DNA (genotoxicity) or cause oxidative stress to human cells (cytotoxicity). The occurrence of the carbonyl compounds in wine may involve enzymatic reactions. Therefore, deletion of some enzymes of microorganisms is a strategy to reduce the levels of the free forms of these compounds in wines. Regarding acrolein and furfural, environmental contamination of grapes contributes to their presence in wines and the reduction of contamination may be achieved by replacing wood for other heat sources in fireplaces and burning stove stones, in addition to abandon the practice of burning garbage and vegetation around vineyards. 


\section{DECLARATION OF CONFLICT OF INTERESTS}

The authors declare no conflict of interest. The founding sponsors had no role in the design of the study; in the collection, analyses, or interpretation of data; in the writing of the manuscript, and in the decision to publish the results.

\section{AUTHORS' CONTRIBUTIONS}

The authors contributed equally to the manuscript.

\section{REFERENCES}

AJTONY, Z. et al. Determination of ethyl carbamate in wine by high performance liquid chromatography. Food Chemistry, v.141, n.2, p.1301-1305, 2013. Available from: <http://dx.doi org/10.1016/j.foodchem.2013.04.011>. Accessed: May, 1, 2019. doi: $10.1016 /$ j.foodchem.2013.04.011.

AZEVEDO, L.C. et al. Evaluation of the Formation and Stability of Hydroxyalkylsulfonic Acids in Wines. Journal of Agricultural and Food Chemistry, v.55, n.21, p.8670-8680, 2007. Available from: <http://dx.doi.org/10.1021/jf0709653>. Accessed: Dec. 2, 2018. doi: 10.1021/jf0709653.

BAUER, R. et al. Acrolein in wine: Importance of 3-hydroxypropionaldehyde and derivatives in production and detection. Journal of Agricultural and Food Chemistry, v.58, n.6, p.3243-3250, 2010a. Available from: <http://dx.doi.org/10.1021/ jf9041112>. Accessed: Dec. 2, 2018. doi: 10.1021/jf9041112.

BAUER, R. et al. Influence of environmental parameters on production of the acrolein precursor 3-hydroxypropionaldehyde by Lactobacillus reuteri DSMZ 20016 and its accumulation by wine lactobacilli. International Journal of Food Microbiology, v.137, n.1, p.28-31, 2010b. Available from: $<$ http://dx.doi.org/10.1016/j. ijfoodmicro.2009.10.012>. Accessed: Dec. 10, 2018. doi: 10.1016/j.ijfoodmicro.2009.10.012.

CARRETÉ, R. et al. Inhibitory effect of sulfur dioxide and other stress compounds in wine on the ATPase activity of Oenococcus oeni. FEMS Microbiology Letters, v.211, p.155-159, 2002. Available from: <http://dx.doi.org/10.1111/j.1574-6968.2002. tb11218.x>. Accessed: Dec. 20, 2018. doi: 10.1111/j.15746968.2002.tb11218.x.

CHEN, W.Y. et al. Acrolein is a pathogenic mediator of alcoholic liver disease and the scavenger hydralazine is protective in mice. Cellular and Molecular Gastroenterology and Hepatology, v.2 n.5, p.685-700, 2016. Available from: $<$ http://dx.doi.org/10.1016/j. jcmgh.2016.05.010>. Accessed: May, 1, 2019. doi: 10.1016/j. jcmgh.2016.05.010.

CHUNG, H. et al. Evaluation of volatile organic compounds in alcoholic beverages consumed in Korea. Journal of the Korean Society for Applied Biological Chemistry, v.58, v.3, p.423-432, 2015. Available from: <https://doi.org/10.1007/s13765-015-00591>. Accessed: May, 1, 2019. doi: 10.1007/s13765-015-0059-1.

CUI, X. et al. In vitro toxicological evaluation of ethyl carbamate in human HepG2 cells. Toxicology Research, v.2016, n.5, p.697-702, 2016. Available from: <http://dx.doi.org/10.1039/C5TX00453E $>$. Accessed: Dec. 9, 2018. doi: 10.1039/C5TX00453E.
DAVID, D.; ARKEMAN, H. Evaluation of the oral toxicity of formaldehyde in rats. Universa Medicina, v.27, n.3, p.106-112, 2008. Available from: $<$ http://dx.doi.org/10.18051/UnivMed.2008. v27.106-112>. Accessed: Dec. 9, 2018. doi: 10.18051/ UnivMed.2008.v27.106-112.

DOROKHOV, et al. Metabolic methanol: molecular pathways and physiological roles. American Physiological Society. v.95, n.2, p.603-644, Apr. 2015. Available from: <http://dx.doi.org/10.1152/ physrev.00034.2014>. Accessed: Dec. 2, 2018. doi: 10.1152/ physrev.00034.2014.

EFSA. European Food Safety Authority. Opinion of the Scientific Panel on Food Additives, Flavourings, Processing Aids and Materials in Contact with Food on a request from the Commission related to Furfural and Furfural Diethylacetal. EFSA Journal, v.67, p.1-27, 2004. Available from: <http://www.efsa.europa.eu/ en/efsajournal/pub/67>. Accessed: Aug. 12, 2017.

ERIKSSON, C.J.P. Genetic-epidemiological evidence for the role of acetaldehyde in cancers related to alcohol drinking. Advances in Experimental Medicine and Biology, v.815, p.41-58, 2015. Available from: <http://dx.doi.org/ 10.1007/978-3-319-09614-8_3>. Accessed: Dec. 18, 2018. doi: 10.1007/978-3-319-09614-8_3.

ES-SAFI, N.E. et al. Role of aldehydic derivatives in the condensation of phenolic compounds with emphasis on the sensorial properties of fruit-derived foods. Journal of Agricultural and Food Chemistry, v.50, n.20, p.5571-5585, 2002. Available from: <http://dx.doi.org/10.1021/jf025503y>. Accessed: Dec. 1, 2018. doi: 10.1021/jf025503y.

FERREIRA, D.C. et al. Carbonyl compounds in different stages of vinification and exposure risk assessment through Merlot wine consumption. Food Additives \& Contaminants: Part A, 2018. Available from: <http://dx.doi.org/10.1080/19440049.2018.153953 0>. Accessed: Dec. 10, 2018. doi: 10.1080/19440049.2018.1539530.

FERREIRA, D. C. et al. Development of a method for determination of target toxic carbonyl compounds in must and wine using HSSPME-GC/MS-SIM after preliminary $\mathrm{GC} \times \mathrm{GC} / \mathrm{TOFMS}$ analyses. Food Analytical Methods, v.12, p.108-120, 2019. Available from: $<$ http://dx.doi.org/10.1007/s12161-018-1343-6>. Accessed: Jan. 2, 2019. doi: 10.1007/s12161-018-1343-6.

FUJIOKA, K.; GORDON, S. Effects of "essential AD2" supplement on blood acetaldehyde levels in individuals who have aldehyde dehydrogenase (ALDH2) deficiency. American Journal of Therapeutics, p.1-6, 2018. Available from: <http://dx.doi. org/10.1097/MJT.0000000000000744>. Accessed: Dec. 7, 2018. doi: 10.1097/MJT.0000000000000744.

GONZÁLEZ-CENTENO, M.R. et al. Use of oak wood during malolactic fermentation and ageing: Impact on chardonnay wine character. Food Chemistry, v.278, p.460-468, 2019. Available from: $<$ https://doi.org/10.1016/j.foodchem.2018.11.049>. Accessed: Apr. 25, 2019. doi: 10.1016/j.foodchem.2018.11.049.

HASEEB, S. et al. Wine and cardiovascular health a comprehensive review. Circulation, v.136, n.15, p.14341448, 2017. Available from: <http://dx.doi.org/10.1161/ CIRCULATIONAHA.117.030387>. Accessed: Dec. 13, 2018. doi: 10.1161/CIRCULATIONAHA.117.030387.

HUANG, Y.J. et al. Acrolein induces Alzheimer's disease-like pathologies in vitro and in vivo. Toxicology Letters, v.217, n.3, 
p.184-191, 2013. Available from: <http://dx.doi.org/10.1016/j. toxlet.2012.12.023>. Accessed: Dec. 22, 2018. doi: 10.1016/j. toxlet.2012.12.023.

IARC - International Agency for Research on Cancer. Agents Classified by the IARC Monographs, Volumes 1-122. Available from: <https://monographs.iarc.fr/wp-content/uploads/2018/09/ List_of_Classifications.pdf $>$. Accessed: Apr. 29, 2019.

IPCS - International Programme on Chemical Safety (2002). Formaldehyde. Geneva: World Health Organization (Concise International Chemical Assessment Document 40). Available from: $<$ http://apps.who.int/iris/bitstream/10665/42430/1/a73769.pdf>. Accessed: Dec. 10, 2018.

ISMAHIL, M. A. et al. Chronic oral exposure to the aldehyde pollutant acrolein induces dilated cardiomyopathy. American Journal of Physiology - Heart and Circulatory Physiology, v.301, p.H2050-H2060, 2011. Available from: <http://dx.doi. org/10.1152/ajpheart.00120.2011>. Accessed: Dec. 2, 2018. doi: 10.1152/ajpheart.00120.2011

JACKOWETZ, J.N. et al. Multifactorial analysis of acetaldehyde kinetics during alcoholic fermentation by Saccharomyces cerevisiae. Food Research International, v.44, n.1, p.310-316, 2011. Available from: <http://dx.doi.org/10.1016/j.foodres.2010.10.014>. Accessed: Dec. 11, 2018. doi: 10.1016/j.foodres.2010.10.014.

JAYAKODY, L.N. et al. Mitigating health risks associated with alcoholic beverages through metabolic engineering. Current Opinion in Biotechnology, v.37, p.173-181, 2016. Available from: $<$ http://dx.doi.org/10.1016/j.copbio.2015.12.001>. Accessed: Dec. 23, 2018. doi: 10.1016/j.copbio.2015.12.001.

JECFA - Evaluations of the Joint FAO/WHO Expert Committee on Food Additives (JECFA). 2018a. Available from: <http://apps. who.int/food-additives-contaminants-jecfa-database/search.aspx> . Accessed: Dec. 10, 2018.

JEONG, H.S. et al. Validation and Determination of the Contents of Acetaldehyde and Formaldehyde in Foods. Toxicological Research, v.31, n.3, p.273-278, 2015. Available from: <http:// dx.doi.org/10.5487/TR.2015.31.3.273>. Accessed: Dec. 2, 2018. doi: 10.5487/TR.2015.31.3.273.

JIAO, Z. et al. Ethyl carbamate in fermented beverages: presence, analytical chemistry, formation mechanism and mitigation proposals. Comprehensive Reviews in Food Science and Food Safety. v.13, n.4, p.611-626, 2014. Available from: <http://dx.doi. org/10.1111/1541-4337.12084>. Accessed: Dec. 2, 2018. doi: 10.1111/1541-4337.12084.

KÄCHELE, M. et al. NMR investigation of acrolein stability in hydroalcoholic solution as a foundation for the valid HS-SPME/ GC-MS quantification of the unsaturated aldehyde in beverages. Analytica Chimica Acta, v.820, p.112-118, 2014. Available from: $<$ http://dx.doi.org/10.1016/j.aca.2014.02.030>. Accessed: Dec. 2, 2018. doi: 10.1016/j.aca.2014.02.030.

KRSTIC, M.P. et al. Review of smoke taint in wine: smokederived volatile phenols and their glycosidic metabolites in grapes and vines as biomarkers for smoke exposure and their role in the sensory perception of smoke taint. Australian Journal of Grape and Wine Research, v.21, n.S1, p.537-553, 2015. Available from: $<$ http://dx.doi.org/10.1111/ajgw.12183>. Accessed: Dec. 2, 2018. doi: $10.1111 /$ ajgw.12183.
LACHENMEIER, D.W. et al. Occurrence of carcinogenic aldehydes in alcoholic beverages from Asia. International Journal of Alcohol and Drug Research. v.2, n.2, p.31-36, 2013. Available from: <http://dx.doi.org/10.7895/ijadr.v2i2.88>. Accessed: Dec. 2, 2018. doi: 10.7895/ijadr.v2i2.88.

LAGO, L.O. et al. Influence of ripeness and maceration of the grapes on levels of furan and carbonyl compounds in wine Simultaneous quantitative determination and assessment of the exposure risk to these compounds. Food Chemistry, v.230, p.594-603, 2017. Available from: <http://dx.doi.org/10.1016/j. foodchem.2017.03.090>. Accessed: Dec. 2, 2018. doi: 10.1016/j. foodchem.2017.03.090.

LAJOVIC, A. et al. Carcinogenesis of urethane: simulation versus experiment. Chemical Research in Toxicology, v.28, n.4, p.691701, 2015. Available from: $<\mathrm{http}: / / \mathrm{dx}$.doi.org/10.1021/tx500459t>. Accessed: Dec. 2, 2018. doi: 10.1021/tx500459t.

LAKE, B.G et al. Lack of effect of furfural on unscheduled DNA synthesis in the in vivo rat and mouse hepatocyte DNA repair assays and in precision-cut human liver slices. Food and Chemical Toxicology, v.39, n.10, p.999-1011, 2001. Available from: <http:// dx.doi.org/10.1016/S0278-6915(01)00050-3>. Accessed: Dec. 2, 2018. doi: 10.1016/S0278-6915(01)00050-3.

LEÇA, J.M. et al. A sensitive method for the rapid determination of underivatized ethyl carbamate in fortified wine by liquid chromatography-electrospray tandem mass spectrometry. Food Analytical Methods, v.11, n.2, p.327-333, 2018. Available from: $<$ https://sci-hub.tw/10.1007/s12161-017-1002-3>. Accessed: Apr. 25, 2019. doi: 10.1007/s12161-017-1002-3.

LEWIS, S.J.; SMITH, G.D. Alcohol, ALDH2, and esophageal cancer: a meta-analysis which illustrates the potentials and limitations of a mendelian randomization approach. Cancer Epidemiology, Biomarkers \& Prevention, v.14, n.8, p.19671971, 2005. Available from: <http://dx.doi.org/10.1158/10559965.EPI-05-0196>. Accessed: Dec. 2, 2018. doi: 10.1158/10559965.EPI-05-0196.

LIU, H. et al. Ethyl carbamate induces cell death through its effects on multiple metabolic pathways. Chemico-Biological Interactions, v.277, p.21-32, 2017. Available from: $<$ http://dx.doi. org/10.1016/j.cbi.2017.08.008>. Accessed: Dec. 2, 2018. doi: 10.1016/j.cbi.2017.08.008.

MARTÍNEZ-GIL, A.M. et al. Volatile composition and sensory characteristics of Carménère wines macerating with Colombian (Quercus humboldtii) oak chips compared to wines macerated with American $(Q$. alba) and European (Q. petraea) oak chips. Food Chemistry, v.266, p.90-100, 2018. Available from: $<$ http://dx.doi. org/10.1016/j.foodchem.2018.05.123>. Accessed: Dec. 2, 2018. doi: 10.1016/j.foodchem.2018.05.123.

MENEGOLA, E. et al. Acetaldehyde in vitro exposure and apoptosis: a possible mechanism of teratogenesis. Alcohol, v.23, n.1, p.35-39, 2001. Available from: <http://dx.doi.org/10.1016/ S0741-8329(00)00132-4>. Accessed: Dec. 2, 2018. doi: 10.1016/ S0741-8329(00)00132-4.

NÓBREGA, I.C.C. et al. Improved sample preparation for GCMS-SIM analysis of ethyl carbamate in wine. Food Chemistry, v.177, p.23-28, 2015. Available from: <http://dx.doi.org/10.1016/j. foodchem.2014.12.031>. Accessed: Dec. 2, 2018. doi: 10.1016/j. foodchem.2014.12.031. 
OLIVEIRA, C.M. et al. Oxidation mechanisms occurring in wines. Food Research International, v.44, n.5, p.11151126, 2011. Available from: <http://dx.doi.org/10.1016/j. foodres.2011.03.050>. Accessed: Dec. 2, 2018. doi: 10.1016/j. foodres.2011.03.050.

PERESTRELO, R. et al. Impact of storage time and temperature on furanic derivatives formation in wines using microextraction by packed sorbent tandem with ultrahigh pressure liquid chromatography LWT - Food Science and Technology, v.76, p.40-47, 2017. Available from: <http://dx.doi.org/10.1016/j.lwt.2016.10.041>. Accessed: Nov. 29, 2018. doi: $10.1016 /$ j.lwt.2016.10.041.

PICARIELLO, L. et al. Enological tannins affect acetaldehyde evolution, colour stability and tannin reactivity during forced oxidation of red wine. International Journal of Food Science and Technology, v.53, n.1, p.228-236, 2017. Available from $<$ http://dx.doi.org/10.1111/ijfs.13577>. Accessed: Nov. 9, 2018 doi: $10.1111 /$ ijfs. 13577.

PISSARRA, J. et al. Reaction between malvidin 3-glucoside and $(+)$-catechin in model solutions containing different aldehydes. Journal of Food Science, v.68, n.2, 2003. Available from: <https:// doi.org/10.1111/j.1365-2621.2003.tb05697.x>. Accessed: Apr. 25, 2019. doi: $10.1111 /$ j.1365-2621.2003.tb05697.

ROCHA, S.M. et al. Occurrence of furfuraldehydes during the processing of Ouercus suber L. cork. Simultaneous determination of furfural, 5-hydroxymethylfurfural and 5-methylfurfural and their relation with cork polysaccharides. Carbohydrate Polymers, v.56, n.3, p.287-293, 2004. Available from: <http://dx.doi. org/10.1016/j.carbpol.2004.03.002>. Accessed: Nov. 1, 2018. doi: 10.1016/j.carbpol.2004.03.002.

RUIZ-BEJARANO et al. Effect of ageing of sweet Sherry wines obtained from cvs Muscat and Pedro Ximénez on ethyl carbamate concentration. Australian Journal of Grape and Wine Research, v.21, p.396-403, 2015. Available from: <http:// dx.doi.org/10.1111/ajgw.12147>. Accessed: May, 5, 2019. doi: 10.1111/ajgw.12147.

SANTOS, F et al. Acacia, cherry and oak wood chips used for a short aging period of rosé wines: effects on general phenolic parameters, volatile composition and sensory profile. Journal of the Science of Food and Agriculture, v.99, n.7, p.35883603, 2019. Available from: <https://doi.org/10.1002/jsfa.9580>. Accessed: May, 1, 2019. doi: 10.1002/jsfa.9580.

SEMCHYSHYN, H.M. Reactive Carbonyl Species In Vivo: Generation and Dual Biological Effects. The Scientific World Journal, v.2014, 2014. Available from: <http://dx.doi. org/10.1155/2014/417842>. Accessed: Apr. 25, 2019. doi: $10.1155 / 2014 / 417842$
SHERIDAN, M.K.; ELIAS, R.J. Exogenous acetaldehyde as a tool for modulating wine color and astringency during fermentation Food Chemistry, v.177, p.17-22, 2015. Available from: <http:// dx.doi.org/10.1016/j.foodchem.2014.12.077>. Accessed: Nov. 15, 2018. doi: 10.1016/j.foodchem.2014.12.077.

WANG, J. et al. Rosé wine volatile composition and the preferences of Chinese wine professionals. Food Chemistry, v.202, p.507-517, 2016a. Available from: <http://dx.doi.org/10.1016/j.foodchem.2016.02.042>. Accessed: May, 1, 2019. doi: 10.1016/j.foodchem.2016.02.042.

WANG, J. et al. Chemical and sensory profiles of rosé wines from Australia. Food Chemistry, v.196, p.682-693, 2016b. Available from: $<$ http://dx.doi.org/10.1016/j.foodchem.2015.09.111>. Accessed: May, 1, 2019. doi: 10.1016/j.foodchem.2015.09.111.

WANG, Y.T. et al. Acrolein acts as a neurotoxin in the nigrostriatal dopaminergic system of rat: involvement of $\alpha$-synuclein aggregation and programmed cell death. Scientific Reports, v.7, v.1, p.1-9, 2017. Available from: <http://dx.doi.org/ 10.1038/ srep45741>. Accessed: Nov. 19, 2018. doi: 10.1038/srep45741.

WU, P. et al. Formation of ethyl carbamate and changes during fermentation and storage of yellow rice wine. Food Chemistry, v.152, p.108-112, 2014. Available from: <http://dx.doi.org/10.1016/j. foodchem.2013.11.135>. Accessed: Dec. 17, 2018. doi: 10.1016/j. foodchem.2013.11.135.

ZERIN, T. et al. Effects of formaldehyde on mitochondrial dysfunction and apoptosis in SK-N-SH neuroblastoma cells. Cell Biology and Toxicology, v.31, n.6, p.261-272, 2015. Available from: <http://dx.doi.org/10.1007/s10565-015-9309-6>. Accessed: Nov. 5, 2018. doi: 10.1007/s10565-015-9309-6.

ZHANG, J. et al. Simultaneous Determination of Ethyl Carbamate and Urea in Alcoholic Beverages by High-Performance Liquid Chromatography Coupled with Fluorescence Detection. Journal of Agricultural and Food Chemistry, v.62, p.2797-2802, 2014. Available from: $<\mathrm{http}: / / \mathrm{dx}$.doi.org/10.1021/jf405400y $>$. Accessed: May, 1, 2019. doi: 10.1021/j4405400y.

ZHANG, J. et al. Modeling of Toxicity-Relevant Electrophilic Reactivity for Guanine with Epoxides: Estimating Hard and Soft Acids and Bases (HSAB) Parameter as a Predictor. Chemical Research in Toxicology, v.29, n.5, 2016. Available from: <http:// dx.doi.org/10.1021/acs.chemrestox.6b00018>. Accessed: Nov. 15, 2018. doi: 10.1021/acs.chemrestox.6b00018.

YAN, T. et al. Acetaldehyde Induces Cytotoxicity of SH-SY5Y Cells via Inhibition of Akt Activation and Induction of Oxidative Stress. Oxidative Medicine and Cellular Longevity, v.2016, 2016. Available from: $<\mathrm{http}: / / \mathrm{dx}$.doi.org/10.1155/2016/4512309>. Accessed: Nov. 2, 2018. doi: 10.1155/2016/4512309. 